\title{
TOŻSAMOŚĆ RELACYJNA. WYBRANE WĄTKI BIBLIJNYCH OPOWIADAŃ O ADAMIE I EWIE Z RDZ 1-3 JAKO ANTROPOLOGICZNE ŹRÓDŁO INSPIRACJI TERAPEUTYCZNEJ
}

DOI: http://dx.doi.org/10.12775/TiCz.2020.001

Streszczenie. Niniejszy artykuł, oparty na solidnych podstawach egzegetycznych, ma za zadanie przedstawić wybrane biblijne wątki antropologiczne obecne w opowiadaniach o Adamie i Ewie (Rdz 1-3), które mogą być przydatne w terapii chrześcijańskiej, ze szczególnym uwzględnieniem terapii małżeńskiej. Podkreślono jednoczesną odmienność i komplementarność mężczyzny i kobiety oraz ich wzajemną nieadekwatność w drodze do szczęścia i spełnienia, które mogą odnaleźć dopiero w Bogu.

Słowa kluczowe: antropologia biblijna; Adam i Ewa; chrześcijańska psychoterapia.

Abstract. Relational identity. Selected threads of biblical stories about Adam and Eve from Gen. 1-3 as an anthropological source of therapeutic inspiration. This article is intended to present, on a solid foundation, selected biblical anthropological threads present in the stories of Adam and Eve (Gen 1-3), which may be useful in Christian therapy, with particular emphasis on marital therapy. The simultaneous difference and complementarity of man and woman were emphasized, as well as their mutual inadequacy on the path to happiness and fulfillment, because these values can be find only in God.

Keywords: biblical anthropology; Adam and Eve; Christian psychotherapy. 


\section{WSTĘP}

Tak zwana „świecka” psychoterapia i psychologia cieszą się dziś ogromnym powodzeniem, w przeciwieństwie do tych form pomocy psychologicznej, które opierają się na wierze w osobowego Boga i czerpiących z Pisma Świętego oraz nauczania Kościoła. Powody bez wątpienia są złożone, ale jednym z najistotniejszych jest przekonanie, że psychologia, psychoterapia i pokrewne im formy oddziaływania na drugiego człowieka, jak na przykład coaching, oparte są na fundamencie naukowym, podczas gdy odwoływanie się do kwestii wiary i religii jest deprecjonowane ze względu na swoją „nienaukowość”. Wśród wielu szkół psychoterapii możemy wprawdzie wyodrębnić psychoterapię integratywną w ujęciu chrześcijańskim ${ }^{1}$, ale dwie inne spośród najpopularniejszych szkól, psychodynamiczna oraz humanistyczna, podchodzą do niej przynajmniej z rezerwą, jeżeli nie z otwartą deprecjacją jej założeń ${ }^{2}$. Tymczasem nie dość, że twórcy obu krytycznych podejść psychologicznych opierają się na założeniach mających więcej wspólnego $\mathrm{z}$ wiarą (nie mylmy tego pojęcia z religią) niż nauką, to jeszcze sama możliwość naukowego istnienia psychologii chrześcijańskiej została w ocenie autora tego artykułu wielokrotnie dowiedziona ${ }^{3}$. Jednocześnie wyraźnie zauważyć można w nowoczesnej psychologii swoistą modę na duchowość, przy czym nosi ona wyraźny rys postmodernistyczny - jest subiektywna, synkretyczna, z wyraźną przewagą elementów wschodnich (hinduizm, buddyzm, konfucjanizm) niż zachodnich w postrzeganiu świata, ale odniesienia do człowieka wywodzą się z zachodniego neoromantyzmu i liberalizmu, stawiając jednostkę ludzką i jej aspiracje w centrum. Ta zdumiewająca mieszanka prowadzi do tworzenia różnych, często absurdalnych z naukowego punktu widzenia teorii. Czasem, jak w przypadku C.G. Junga, subiektywne interpretacje stanowią punkt wyjścia do stworzenia własnego paradygmatu badawczego.

1 Zob. A. Ostaszewska, Psychoterapia integratywna $w$ ujęciu chrześcijańskim, Sopot $2017^{2}$, ss. 200 .

${ }^{2}$ Napisano już na ten temat szereg prac o bogatych odniesieniach bibliograficznych, ostatnio zob. np. P.C. Vitz, Psychologia jako religia, Warszawa 2017, ss. 194; A. Zwoliński, Psychologia zamiast religii? Pułapki i manipulacje, Kraków 2019, ss. 308.

${ }^{3}$ Zob. T. Niemirowski, O możliwości psychologii chrześcijańskiej, Płock 2010, ss. 112 . 
Jung wielokrotnie odwoływał się do tekstów Pisma Świętego, chociaż jego interpretacje były co najmniej kontrowersyjne ${ }^{4}$. Niniejszy artykuł, oparty na solidnych podstawach egzegetycznych, ma za zadanie przedstawić biblijne wątki antropologiczne obecne w opowiadaniach o Adamie i Ewie (Rdz 1-3), które mogą być przydatne w terapii chrześcijańskiej, ze szczególnym uwzględnieniem terapii małżeńskiej. Zaprezentowane treści pojawiają się wybiórczo $\mathrm{w}$ popularnych publikacjach o charakterze poradnikowym, szczególnie w popularnych opracowaniach J. Eldredge’a ${ }^{5}$, ufamy jednak, że przedstawienie ich w pogłębionej formie, $\mathrm{z}$ odniesieniami do oryginalnego języka Pisma Świętego, przyda się tym wszystkim, którzy w Biblii szukają inspiracji do ustalenia kierunku profesjonalnej pracy psychologicznej z drugim człowiekiem.

\section{CZŁOWIEK JAKO OBRAZ I PODOBIEŃSTWO BOGA}

W pierwszym opisie stworzenia świata, czyli w Rdz 1,1-2,3 (lub $2,4 b$ ), wyraźnie zaznaczono, że człowiek stworzony na obraz Boży ${ }^{6}$ to mężczyzna i kobieta rozumiani razem. Wspólnie otrzymują zarówno błogosławieństwo, jak i nakaz rozmnażania się (wzrastania), zaludnienia ziemi i panowania nad nią (opiekowania się nią)7. Jednocześnie, co

4 Zob. D.M. Wulff, Psychologia religii, Warszawa 1999, s. 355-398 (zwł. s. 378nn).

5 Zwł. J. Eldredge, Dzikie serce. Tęsknoty męskiej duszy, Poznań 2003, ss. 216; tenże, Petnia serca, Poznań 2012, ss. 248; tenże, Droga dzikiego serca, Warszawa 2013, ss. 328. Por. J. i S. Eldredge, Urzekająca. Odkrywanie tajemnicy kobiecej duszy, Warszawa 2011, ss. 334 .

6 Szerzej na ten temat zob. W. Pikor, Pytanie o „obraz $i$ podobieństwo” Boże w człowieku (Rdz 1-2), w: Człowiek - ciało i duch. Tom 2. Ujęcie teologiczne, red. K. Krzemiński, K. Olszewska, R. Beszterda, Toruń 2015, s. 31-45.

$7 \mathrm{Na}$ temat wariantu tłumaczenia z LXX greckiego czasownika KATAKYRIEUO, wskazującego zarówno na opiekę, jak i panowanie, oraz za argumentami na rzecz oddania tego czasownika w tłumaczeniu Rdz 1,28 w pierwszym znaczeniu zob. uwagę R. Popowskiego w: tenże, Biblia pierwszego Kościoła, Warszawa 2016, s. 5, przyp. 1. W tekście hebrajskim mamy w tym miejscu rdzeń כבש, którego znaczenie jest bardziej pejoratywne: podbić, gwałcić, upokorzyć, gnębić, ujarzmić, zniewolić. Zob. np. L. Koehler, W. Baumgartner, J.J. Stamm, Wielki słownik hebrajsko-polski i aramejsko-polski Starego Testamentu (dalej: HALOTpl), red. pol. P. Dec, t. I, Warszawa 2008, art. 4070, s. 435. Inaczej jest już w poleceniu panowania nad zwierzętami w tym samym wersecie, gdyż widnieje tam 
dobrze oddaje tłumaczenie zawarte w piątym wydaniu Biblii Tysiąclecia, tekst dotyczący stworzenia człowieka na obraz Boga zawiera interesujący chiazm, który zobrazowany jest poniżej.

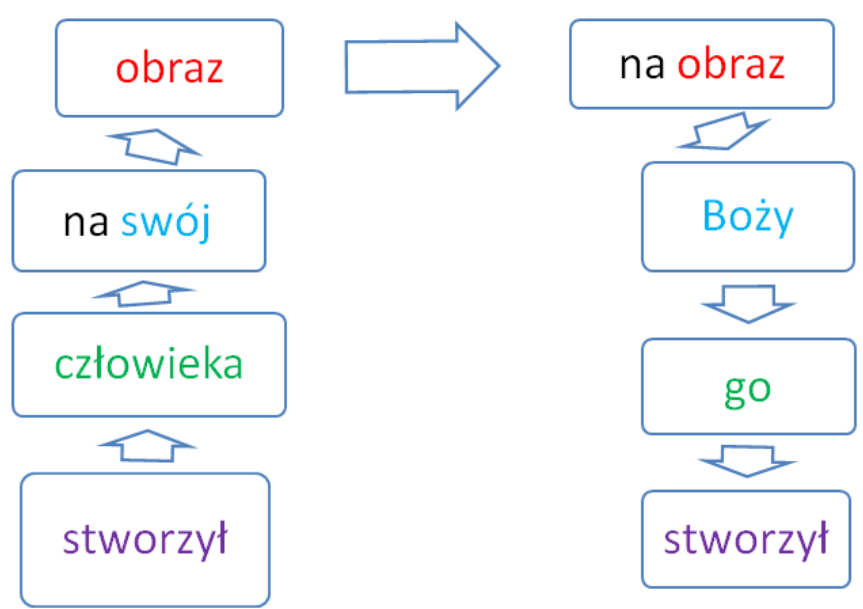

Rysunek 1. Chiazm widoczny w Rdz 1,27 (tłumaczenie BT, wyd. V)

O ile w Rdz 1,26 Bóg mówi o stworzeniu człowieka na swój obraz

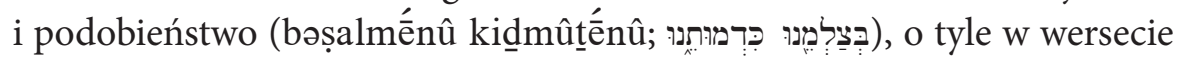

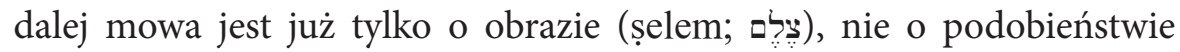
(d mût; דמוּת). „Obraz” niesie w sobie znaczenie „odzwierciedlenia”, czyli ścisłego związku pomiędzy podmiotem a jego odbiciem, a użyty w tekście chiazm dobrze to ilustruje, gdyż obraz pozostaje elementem łączącym, a tym samym centralnym; stanowi punkt spotkania się rzeczywistości boskiej i ludzkiej (w pełni zostało to objawione w osobie Chrystusa).

„Podobieństwo” nie niesie już ze sobą takiej dosłowności. W Biblii używane jest w wielu metaforach, na przykład w Pieśni nad Pieśniami, gdzie „umiłowany” jest „podobny do gazeli, do młodego jelenia”, a jego wybranka do klaczy i palmy ${ }^{8}$, czy też bardzo często w wizjach Ezechiela, zwłaszcza tych dotyczących Bożego rydwanu'. Podobieństwo wskazuje

רדָדה (rādâ), oznaczające „rządzić”, bez pejoratywnych konotacji. Do tematu tego wrócimy w tekście głównym przy opisywaniu Upadku (Rdz 3,1-24).

8 Zob. Pnp 2,9.17; 7,8; 8,14; 1,9 .

${ }^{9}$ Ez 1,5.10.13.16.22.26.28; 10,1.10.21.22. 
więc, gdy używamy go w odniesieniu do istot rozumnych, raczej na adekwatność uczynkową, relacyjną, a nie stricte materialną czy morfologiczną ${ }^{10}$. Widać to wyraźnie w pytaniu Boga do grzesznika: „Czy myślisz, że jestem podobny do ciebie?”, zawartym w Ps 50,21 ${ }^{11}$. Można stąd wysnuć wniosek, że chociaż człowiek jest stworzony na obraz Boży, tak podobieństwo do Boga, wyrażające się w niedostępnej dla innych stworzeń sferze, odkrywa i realizuje we wzajemnej relacyjności pomiędzy mężczyzną i kobietą.

\section{PIERWOTNA SAMOTNOŚĆ}

W drugim opisie stworzenia, $\mathrm{Rdz}$ 2,4-25, mamy interesujące uszczegółowienie. Bóg początkowo stwarza mężczyznę, ale po pewnym czasie stwierdza, żę „nie jest dobrze, żeby mężczyzna był sam” (Rdz 2,18). Bóg tworzy dla mężczyzny „odpowiednią pomoc” w postaci zwierząt, ale chociaż ten nazywa (a więc nadaje znaczenie) wszystkie przyprowadzane do siebie istoty, nie znajduje dla siebie tej pomocy. Co ciekawe, ów brak w dobroci stworzenia, samotność mężczyzny, dostrzega i werbalizuje Bóg, nie mężczyzna. Nie sposób w tym miejscu nie zauważyć zaskakującej rzeczy - jeszcze przed pojawieniem się kobiety mężczyzna w relacji $\mathrm{z}$ Bogiem doświadcza pewnej nieadekwatności, funkcjonując w relacji $\mathrm{z}$ innymi stworzonymi istotami żywymi (sam jest przecież tak nazwany $\mathrm{w}$ akcie stworzenia - zob. Rdz 2,7) i z Bogiem, niejako rozpięty pomiędzy dwiema płaszczyznami, materialną i duchową ${ }^{12}$. Wbrew popularnym wyjaśnieniom antropologicznym, postrzegającym opisaną tu samotność jako doświadczenie przede wszystkim ludzkie ${ }^{13}$, to tekst biblijny jednoznacznie

10 Zaznaczmy, że podobieństwo przedmiotów także jest zaświadczone w Biblii zob. $2 \mathrm{Krl}$ 16,10, gdzie jest mowa o zbudowaniu przez Uriasza ołtarza do Świątyni Jerozolimskiej na podobieństwo i według planów ołtarza widzianego przez Achaza w Damaszku.

11 Por. Iz 40,18.25; 46,5.

12 W Rdz 1,26, podobnie jak w Rdz 2,4, wyraz אָדָ ('ādām) pojawia się bez rodzajnika, co interpretuje się tak, że „człowiek” jest tam określeniem gatunkowym (jako ludzkość). Istoty ludzkie są więc stworzone na obraz i podobieństwo Boga oraz są istotami żywymi (podobnie jak zwierzęta).

13 Zob. przykład takiego wyjaśnienia: „Jakie też odcienie i barwy ludzkiej samotności kryją się za Bożą konstatacją: Nie jest dobrze, żeby człowiek był sam? Jan Paweł II 
wskazuje na mężczyznę, Adama. Męska samotność ma w sobie komponenty, których w Biblii nie zauważymy u kobiety, co wynika z faktu, że ona niemal od początku swojego stworzenia jest $\mathrm{w}$ relacji $\mathrm{z}$ mężczyzną. Trudno jest też mówić o samotności ludzkiej jako tako, gdyż uwarunkowania płciowe i różnice poznawcze $\mathrm{z}$ nich wynikające są pierwotne i podstawowe, stanowiąc jeden $\mathrm{z}$ fundamentów ludzkiej tożsamości.

Pozostaje pytanie otwarte, czy Adam zdawał sobie sprawę ze swej samotności. Można przypuszczać, że tak, a jest ku temu istotna przesłanka. W bardzo tajemniczym wydarzeniu, niedostępnym dla mężczyzny (bo wtedy śpi), Bóg buduje z części mężczyzny kobietę, którą ten określa „dopiero [...] kością z jego kości i ciałem z jego ciała” (Rdz 2,22; podkreślenie własne). Słowo „dopiero” wskazuje na pewną niecierpliwość, na szukanie kogoś, kto okaże się odpowiedni. Pragnienie to jest tak silne, że związek mężczyzny i kobiety stanowi nową jakość (stają się „jednym ciałem”), ale jest $\mathrm{w}$ tym opowiadaniu bardzo subtelna nuta niepokoju. Mężczyzna, chcąc złączyć się z kobietą, „opuszcza ojca swego i matkę swoją” (Rdz 2,24). Kto jest ojcem dla pierwszego mężczyzny, Adama? Bóg. Pustka, którą pragnie zapełnić mężczyzna, wchodząc $\mathrm{w}$ relację z kobietą, grozi „opuszczeniem” Boga, odejściem od Niego. To „opuszczenie” jest pod względem egzystencjalnym niezwykle interesującym zagadnieniem, gdyż w myśl Rdz 1,27-31 mężczyzna tylko z kobietą jest w stanie wypełnić Boże polecenia, poza tym razem z nią jest częścią tego, co „bardzo dobre”. Poza tym, jak zauważyliśmy, Adam jeszcze przed stworzeniem kobiety jest w jakiś sposób samotny. Czy kobieta jest w stanie zapełnić ową pustkę?

od razu dostrzega, że tłumaczenie Biblii Tysiąclecia: Nie jest dobrze, żeby mężczyzna byt sam skupia niepotrzebnie uwagę na płci, na męskiej samotności. Adam jest człowiekiem i przeżywa samotność jako człowiek. Dolega mu brak podobnych do niego. Jego samotność jest samotnością człowieka, a nie tylko samotnością mężczyzny. Papież napisze: «Wydaje się więc, na podstawie pełnego kontekstu, że owa samotność ma dwojakie znaczenie: jedno - wynikające z natury człowieka, czyli z człowieczeństwa (i to w opisie Rdz 2 uwydatnia się przede wszystkim), drugie - wynikające z odniesienia mężczyzny do kobiety, które uwydatnia się niejako na gruncie pierwszego»". M. Grabowski, Historia upadku. Ku antropologii adekwatnej, Kraków 2011, s. 56 (zob. cały rozdział pt. Samotność Adama - w strone interpretacji komplementarnej, s. 56-89). Por. Jan Paweł II, Mężczyzna i niewiasta stworzył ich: odkupienie ciała a sakramentalność małżeństwa, Watykan 1986, s. 24. 


\section{ODPOWIEDNIA POMOC}

Napięcie pomiędzy relacją z Bogiem a relacją z kobietą trafnie oddaje przytoczony już zwrot „pomoc odpowiednia dla niego”, w języ-

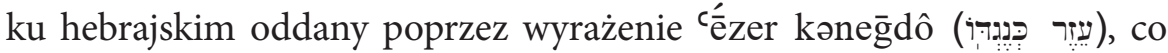
dosłownie oznacza pomoc będącą naprzeciwko, na zasadzie kontrastu czy drugiej strony tej samej rzeczy ${ }^{14}$. Teologia żydowska wypracowała bardzo interesujące interpretacje tego wyrażenia. Midrasz Bereszit Rabba przytacza słowa rabinów Jeremiasza ben Leazara i Samuela ben Namana, według których Bóg stworzył pierwotnie człowieka jako hermafrodytę, posiadającego wszystkie części ciała podwójne, natomiast zrośniętego plecami tak, że mężczyzna i kobieta nie mieli ze sobą kontaktu twarzą $\mathrm{w}$ twarz, nie mogli też prowadzić ze sobą dialogu ${ }^{15}$. Dopiero na pewnym etapie dzieła stwarzania człowieka mężczyzna i kobieta zostali oddzieleni od siebie, co umożliwiło im ten kontakt ${ }^{16}$. Shmuel Trigano powtarza popularny, bo użyty także w Biblii klucz etymologiczny, że rdzeń, od którego pochodzi imię Ewa, oznacza także „rozmowę” i „dialog”, stąd też Ewa ma być nazwana „rozmówczynią Adama” ${ }^{17}$. Być może echa tych interpretacji

${ }_{14}$ Zob. L. Koehler, W. Baumgartner, J.J. Stamm, The Hebrew and Aramaic Lexicon of the Old Testament (dalej: HALOT), CD-ROM Edition, Leiden 2000, art.

${ }_{15}$ Midrasz Bereszit Rabba 8, 1; https://archive.org/stream/RabbaGenesis/midrashrabbahgen027557mbp\#page/n101/mode/2up (dostęp: 30.11.2017).

${ }^{16}$ W Berachot 61 znajdujemy interesującą dyskusję dotyczącą części ciała, którymi mogli być zrośnięci mężczyzna i kobieta (ale też z której części ciała mężczyzny mogła być stworzona kobieta). Zob. https://halakhah.com/pdf/zeraim/Berachoth.pdf (dostęp: 30.11.2017). Por. Eruvin 18a, http://halakhah.com/pdf/moed/Eiruvin.pdf (dostęp: 30.11.2017).

17 Zob. Sh. Trigano, Judaizm: „Mężczyzną i niewiastą stworzył ich”, w: Encyklopedia religii świata, t. 2: Zagadnienia problemowe, red. F. Lenoir, Y. Tardan-Masquelier, M. Meslin, J.-P. Ros, Warszawa 2002, s. 1661-1665. Trigano powołuje się na poparcie swoich słów na Midrasz Bereszit Rabba 20,27 - odnośnik ten jest błędny, gdyż takiego wersetu nie ma w tym midraszu, poza tym uwaga dotycząca „dialogu” nie jest do końca trafna. Jak czytamy m.in. w internetowym słowniku Abarim Publications' online Biblical Hebrew Dictionary, http://www.abarim-publications.com/Meaning/Eve.html\#.Wi_VsnlG2M- (dostęp: 12.12.2017), imię Ewa jest błędnie odnoszone do rdzenia "nַ (hay); wywodzi się według tego źródła raczej z trzech niezależnych rdzeni הוח, które oznaczać mogą gromadzenie, deklarowanie (czegoś), pokorę. Por. R.L. Harris, G.L. Archer, Jr., B.K. Waltke, Theological Wordbook of the Old Testament, Chicago, Illinois 1980 (dalej: TWOT), art. 617-619. 
widać w samym języku hebrajskim, gdyż słowo oznaczające twarz, פִ̣ (pānîm), używane jest w Biblii tylko w liczbie podwójnej ${ }^{18}$.

Pomimo komplikacji interpretacyjnych związanych z użyciem w Rdz 1,27 rodzajnika określonego przy דָָָד (hā'ādām), co w niektórych legendach żydowskich interpretowano tak, że stworzona pierwotnie przez Boga istota ludzka była androgyniczna, pomocą w hermeneutyce tekstu jest Rdz 5,1-2, gdzie jasno czytamy, że nazwa „człowiek” lub „ludzkość” (ujęcie gatunkowe) oznacza mężczyznę i kobietę w ich najbardziej fundamentalnym, płciowym wymiarze - stąd też na określenie mężczyzny użyte

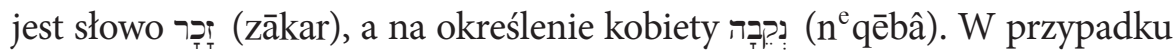
obu słów ich pochodzenie jest złożone. W sensie najbardziej dosłownym

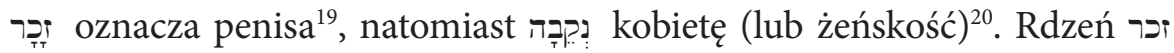
ma jednak bardzo bogate pole semantyczne, obejmujące nazywanie, pamiętanie, wspominanie, wyznawanie, wychwalanie, a także bycie silnym; wreszcie, w nawiązaniu do rozumienia dosłownego, wskazuje także na

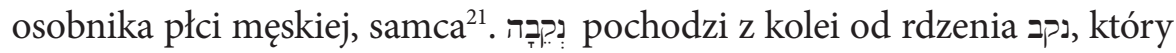
w swym pierwotnym polu semantycznym obejmuje: dziurę, przewiercanie, przebijanie, ale też znakowanie, bluźnienie, tunel, wąwóz, podziemne przejście, kopalnię ${ }^{22}$.Według jednego ze słowników נֶ: (neqeb) może oznaczać także jakiś efekt pracy jubilerskiej, tak więc kobieta byłaby w tym wypadku ukoronowaniem opus ornationis ${ }^{23}$. W człowieku mamy więc, z wyraźnymi aluzjami fizjologicznymi, podział na męskość i kobiecość.

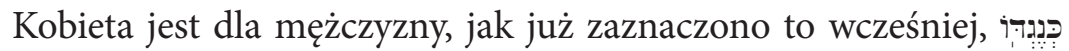
עִזר ('ézer kəneḡdô), co tłumaczy się jako „pomoc odpowiednia dla niego”. Wyjątkowo zajmijmy się tu na początku drugim słowem, wskazującym na „odpowiedniość". נֶֶֶ (neged) to dosłownie coś przeciwległego, coś, co czemuś odpowiada, co jest bezpośrednio przed czymś, naprzeciwko, z przeciwnej strony ${ }^{24}$. Rdzeń, od którego pochodzi to słowo, נג, w swoim

18 TWOT, art. 1782.

19 HALOTpl, art. 2433.

${ }^{20}$ HALOTpl, art. 6196.

${ }^{21}$ Zob. HALOTpl, art. 2431-2435.

${ }^{22}$ Zob. HALOTpl, art. 6194-6195.

${ }^{23}$ Zob. TWOT, art. 1409. Por. P. Briks, Podręczny słownik hebrajsko-polski i aramejsko-polski Starego Testamentu, Warszawa 1999, s. 234, art. נקֶ:

${ }^{24}$ HALOTpl, art. 5836. 
polu semantycznym mieści w sobie znaczenia: zawiadamiać, usiłować przekonać, prowadzić, oznajmiać, zaświadczać, powiadamiać. Od tego rdzenia pochodzi też słowo נִָּ (nāgîd), oznaczające przywódcę, księcia, oficera, wodza czy - uwaga - głowę rodziny ${ }^{25}$. עֵ $z$ kolei tłumaczone jest zwykle jako pomoc, wsparcie ${ }^{26}$. Zaznaczmy tu wyraźnie, że podmiot świadczący wsparcie nie musi mieć roli podrzędnej - wyraźnym tego dowodem jest wielokrotne wzmiankowanie Boga jako עִזר dla swojego ludu ${ }^{27}$. עי, na co zwrócił uwagę m.in. R. D. Freedman, może być kombinacją dwóch rdzeni, oznaczających „ratować, ocalać” i „być silnym” w takim wypadku עי שִ będzie siłą, mocą, i to mocą aktywną, ratującą ${ }^{28}$. ‘ézer kəneḡdô będzie dodatkowo umożliwiała bycie wodzem i przywódcą, a także głową rodziny. Mężczyzna poprzez relację z kobietą ma możliwość stać się „księciem”, tym samym wpisując się w jeden z najpowszechniejszych archetypów cywilizacji zachodniej. Co istotne, księciem tym ma być w pierwszej kolejności dla niej, a nie tylko dzięki niej. Nawiązując do kulturowego archetypu księcia, nie mamy tu na myśli negatywnie postrzeganego, patriarchalnego tyrana $\mathrm{z}$ feministycznych teorii, którego marzeniem jest wykorzystywać kobietę i odbierać jej wszelkie prawa, ale raczej księcia-wojownika, który będzie chronił ją przed złem, wyzwalał z niewoli i czynił z niej księżniczkę, a następnie królową.

\section{TOŻSAMOŚĆ RELACYJNA CZłOWIEKA}

Podsumujmy dotychczasowe ustalenia, stosując do nich klucz antropologiczny. W pierwotnym ujęciu mężczyzna jest tym, który wychwala Boga, nazywa stworzenia, który daje wyraz swojej ekspresji twórczej, ale niesie w sobie egzystencjalną samotność, poczucie nieadekwatności, inności - zarówno w odniesieniu do Boga, jak i do świata stworzonego. Kobieta jest dla niego niejako ratunkiem przed tą samotnością, gdyż ona

25 TWOT, art. 1289; HALOTpl, art. 5843.

${ }^{26}$ HALOTpl, art. 6788-6792.

27 Zob. np. Wj 18,4; Pwt 33,7.29; Ps 20,3; 115,9-11; 121,2; 124,8.

28 Zob. HALOTpl, art. 6789, 6793. Szerzej na temat tłumaczenia omawianego wyrażenia zob. Trudne fragmenty Biblii, red. W.C. Kaiser Jr., P.H. Davids, F.F. Bruce, M.T. Brauch, Warszawa 2011, s. 8-10. 
także potrafi się komunikować (chociaż nie nazywa stworzeń!). Wzajemnie stanowią dla siebie uzupełnienie, są dwoma biegunami jednej rzeczywistości. Kobieta wprowadza w ludzkie życie relacyjność i w jakimś stopniu umożliwia mężczyźnie spojrzenie na siebie z dystansu i zdefiniowanie na nowo swojej tożsamości. Ich pierwotną harmonię oddaje użyta przez Adama gra słów, kiedy to nazywa nie tylko kobietę mianem ('ishshâ), ale i siebie - אִי ('îsh). W sytuacji przed upadkiem, chociaż różnią się od siebie, żyją w harmonii, wzajemnie się poznając i określając własne działania. Biblijny autor, obrazowo wskazując na różnice zachodzące pomiędzy płciami, wykazał się dużym zmysłem psychologicznym. Warto wskazać tutaj niektóre tropy, osobno dla każdej płci.

Mężczyzna od początku swojego stworzenia jest odpowiedzialny za świat, w którym umieścił go Bóg. Ma uprawiać i doglądać rajski ogród, jest też powiernikiem pierwszego zakazu - nie jeść z drzewa poznania dobra i zła. W dużej mierze to on określa funkcje powierzonego mu świata, będąc odpowiedzialnym zarówno za słowo wypowiadane przez siebie (nazywanie zwierząt), jak też mu powierzone (przykazanie). Pracując i porządkując rzeczywistość dokoła siebie nie jest jednak w stanie samotnie wzbić się ponad to, kim sam jest - będąc „istotą żywą” (Rdz $2,7)$ wszelkie inne istoty nazywa tak samo ( $\mathrm{Rdz} 2,19)$. Swoją tożsamość relacyjną odkrywa dopiero wskutek odczucia braku „pomocy odpowiedniej dla niego".

Warto zadać pytanie, dlaczego Bóg, myśląc o uczynieniu Adamo-

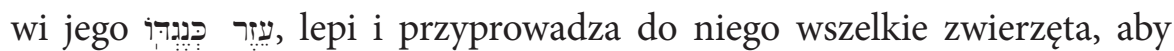
się przekonać, jak ten je nazwie? Czyżby Bóg nie wiedział, że ta część stworzenia nie będzie adekwatna do zapełnienia przestrzeni samotności w Adamie? A może to Adam potrzebował takiego doświadczenia, które miało go przygotować na spotkanie z kobietą? W tekście hebrajskim mamy interesujące zjawisko: w opisie zbudowania kobiety $\mathrm{z}$ adamowego

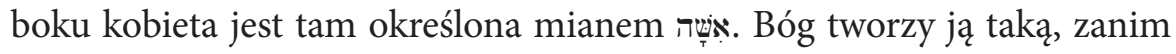

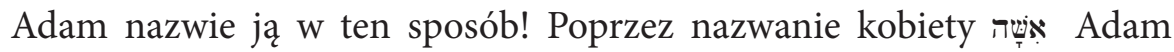
odkrywa nowy wymiar swojego bytowania, dokonuje samookreślenia w relacji do kobiety. Samookreślenie to nie jest jednak trwałe - w dalszej części tekstu ciągle jest nazywany הָזָד odnosząc się do kobiety mianem אָזָׁ. Kobieta $\mathrm{z}$ kolei od samego początku swojego stworzenia ukierunkowana jest na relację z nim i to stanowi rdzeń jej istoty. 


\section{DRZEWO POZNANIA, DRZEWO ŻYCIA}

Przejdźmy teraz do drzewa poznania dobra i zła. Mówiliśmy już, że mężczyzna był odpowiedzialny za słowo - i to określające byt stworzonych istot, i to zawierające Boży zakaz. Zauważmy, podążając ściśle za tekstem biblijnym, że tylko mężczyzna (הָאָָָד) otrzymał ten zakaz, tylko on słyszał go bezpośrednio od Boga. Skąd wynika więc niedokładne przytoczenie go podczas rozmowy $\mathrm{z}$ wężem $\mathrm{w} \operatorname{Rdz} 3,2$ ? Z wyolbrzymienia, czy też $\mathrm{z}$ niedokładnego przekazania zakazu przez mężczyznę? I jeszcze bardziej podstawowe pytanie: czym było owo drzewo i dlaczego człowiek nie mógł sięgać po owoce dające poznanie dobra i zła? Wśród wielu interpretacji wskażmy na takie, które mogą mieć znaczenie w zastosowaniu tekstu biblijnego do pracy terapeutycznej.

Zdzisław Pawłowski czyni spostrzeżenie, że drzewo znajomości dobra i zła, stanowiąc figurę mądrości potrzebnej człowiekowi w trudzie uprawy ziemi, jest jednocześnie obwarowane zakazem spożywania z jego owoców. W ten sposób aktywność człowieka, w której mądrość połączona jest z przykazaniem, ma wymiar etyczny ${ }^{29}$. Z tą aktywnością, z ludzką pracą, która może zapewnić człowiekowi realizowanie pragnień (potrzeb), związana jest odpowiedzialność oparta na osobowym zaufaniu najpierw na linii człowiek - Bóg, a następnie na linii człowiek - człowiek. W pierwotnym porządku stworzenia ludzkie pragnienia i możliwość ich realizacji są integralnie związane $\mathrm{z}$ relacją osobową, a tym samym linią wyznaczającą ich granice jest podmiotowość i godność każdej osoby. Wobec adamowej samotności tym, co nadaje sens jego istnieniu, jest „budowanie osobowych więzi w całokształcie relacji, konstytuujących jego tożsamość i nadawanie stworzeniu osobowego ładu, w czym naśladuje samego Boga”30. Połączenie poszukiwania mądrości z koniecznością przestrzegania przykazania w naturalny sposób podkreśla aspekt zaufania wobec Boga, który pozostaje zasadniczym punktem odniesienia dla istoty ludzkiej. Po pojawieniu się kobiety odniesienie to rozszerza się jeszcze, staje się nawet bardziej adekwatne poprzez relacyjność opartą już nie

29 Z. Pawłowski, Narracja i egzystencja. Genesis w hermeneutyce opowieści, Toruń 2013, s. 132 n.

30 Tamże, s. 133. 
tylko na podobieństwie, ale na istotowej naturze mężczyzny i kobiety („kość z kości” i „ciało z ciała”; Rdz 2,23). Pierwsza ludzka para jest więc zaproszona do tego, aby razem odkrywać swoje osobowe podobieństwo do Stwórcy, tworzącego świat nie dla własnego, egoistycznego kaprysu, ale aktualizowania jego dobra i dbania o niego. Widać to wyraźnie w stopniowaniu czasowników dotyczących „panowania” nad ziemią. O ile w Rdz 1,28 w przykazaniu dotyczącym czynienia sobie ziemi poddaną owo „poddanie” jest oddane poprzez כָָבָּש (kābash), co dosłownie można przetłumaczyć jako: „podbić, gwałcić, upokorzyć, pognębić”31, o tyle w odniesieniu do panowania nad zwierzętami mamy już רדָ (rādâ), czyli „rządzić, panować” bez komponentu przemocy ${ }^{32}$. Jeszcze bardziej zmianę tę widać w opowiadaniu zawartym w Rdz 2,4 nn., w którym Adam umieszczony zostaje $\mathrm{w}$ ogrodzie zasadzonym przez Boga. Adam zostaje umieszczony $\mathrm{w}$ tym ogrodzie, aby być jego strażnikiem i opiekunem, a nie ciemiężycielem. W Rdz 2,15 znajdujemy informację, że Bóg osadził człowieka w ogrodzie, aby go „uprawiał i strzegł”. W języku hebrajskim mamy tam słowa: אעבֵד ('ābad), oznaczające „pracować, służyć” (od tego samego rdzenia pochodzi עֶבֶ ('ebed), „sługa, niewolnik”) (shāmar), „pilnować, doglądać, zachowywać, strzec”34.

\section{IMPLIKACJE ANTROPOLOGICZNE WYNIKAJĄCE Z DWÓCH OPOWIADAŃ O STWORZENIU CZŁOWIEKA}

Zauważmy, że w obu opowiadaniach o stworzeniu człowieka diametralnie inaczej ukazany jest kontekst jego początkowego egzystowania. W pierwszym opowiadaniu człowiek jest „koroną stworzenia”. Kiedy Bóg uczynił już niebo i ziemię i zapełnił życiem każdy zakątek uczynionego przez siebie świata, poczynając od roślin wydających nasiona i drzew owocowych rodzących właściwe sobie owoce ( $R d z 1,11)$, poprzez zarojenie wód mnóstwem istot żywych i stworzeniem ptaków latających pod sklepieniem nieba, aż po powołanie do istnienia wszelkich gatunków istot

\footnotetext{
${ }^{31}$ Zob. HALOTpl, art. 4070.

32 TWOT, art. 2121.

33 TWOT, art. 1553.

${ }^{34}$ TWOT, art. 2414.
} 
żywych poruszających się po ziemi: zwierząt domowych i dzikich oraz płazów - dopiero wtedy tworzy człowieka. Istota ludzka w pierwszym opowiadaniu jest uczyniona w pięknych, bogatych życiem warunkach. Wszystko to, całe to nieogarnione bogactwo, jest mu oddane do panowania. Człowiek jest stworzony pięknie i jest integralnym elementem tego piękna. O ile stworzenie świata nieożywionego i zwierzęcego jest określane jako „dobre” (czyli także szczęśliwe, odpowiednie, słuszne, udane, przyjemne, korzystne (a nawet zbawienne), pożyteczne, znajdujące się na właściwym miejscu, etc. - pole semantyczne przymiotnika jest szerokie $)^{35}$, tak dopiero poprzez stworzenie człowieka i oddanie mu władzy nad tym światem sprawia, że Boże dzieło staje się „bardzo dobre” $(\operatorname{Rdz} 1,31)^{36}$. Użyte tu słowo מִאז ( $\mathrm{m}^{\mathrm{e}}{ }^{\prime} \overline{\mathrm{o}}$ ) wskazuje na silną (a nawet maksymalną) intensyfikację, obfitość. Przesłanie $\operatorname{Rdz} 1,31$ jest jasne i, zwłaszcza w lekturze narracyjnej czy lectio continua, zdecydowanie podkreślającej usankcjonowanie przez Boga porządku stworzonego świata. Zamyka ono także spekulacje dotyczące zarówno tego, czy człowiek nie jest „nieudanym” elementem stworzenia, jak i tego, czy Bóg nie popełnił błędu, umieszczając w ogrodzie Eden drzewo dające wiedzę o dobru i złu, o którym będzie mowa w Rdz 2,9.

Drugie opowiadanie o stworzeniu człowieka przedstawia zgoła inny punkt wyjścia. W Rdz 2,4-25 Adam (mężczyzna) zostaje ulepiony $\mathrm{z}$ prochu ziemi w bardzo surowych warunkach, na ziemi pozbawionej jakiejkolwiek roślinności. Bóg z tego surowego środowiska przenosi mężczyznę do ogrodu, niemniej jednak pierwotną ojczyzną Adama jest owa ascetyczna kolebka, w której uzyskał świadomość własnego „ja”. Dwukrotnie czytamy o tym, że Adam został „umieszczony” bądź „osadzony” w ogrodzie Eden (Rdz 2,8.15). Trudno jest jednoznacznie wskazać na przyczynę tego powtórzenia. W Rdz 2,8 Adam zostaje umieszczony w ogrodzie tuż przed tym, jak Bóg powołuje do istnienia „różne drzewa o pięknym wyglądzie i smacznych owocach; także drzewo dające życie w środku ogrodu - i drzewo dające wiedzę o dobru i złu” (Rdz 2,8-9,

${ }^{35} \mathrm{Rdz}$ 1,10.18.25. Zob. TWOT, art. 793.

36 TWOT, art. 1134. Por. Rdz 13,13, gdzie jest mowa o wielkiej niegodziwości mieszkańców Sodomy, czy Rdz 7,18, w którym to miejscu czytamy o zalewających świat wodach potopu. Na więcej fragmentów biblijnych z użyciem daom. wskazuje HALOT, art. 4719. 
BP). Następnie, po fragmencie dotyczącym wypływających z Edenu rzek, w Rdz 2,15 znów czytamy o „wzięciu i osadzeniu” Adama w ogrodzie Eden, aby go „uprawiał i strzegł”. Adam zostaje niejako „połączony” z ogrodem (jedno z możliwych znaczeń (śâm) z Rdz 2,8) ${ }^{37}$, aby i tu interesujące zestawienie - „odpoczywać” pracując w Edenie i dbając o niego. „Odpoczywanie”, o którym tu piszemy, to jedno z głównych,

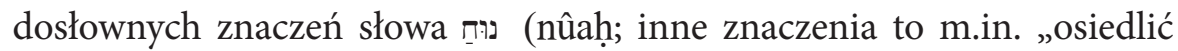
się") ${ }^{38}$. Możliwe jest też odczytanie ㄲּּ jako pozostawienie kogoś po to, aby umożliwić mu odpoczynek, pozostawienie go w spokoju ${ }^{39}$. Perspektywa odejścia Boga od człowieka w tym momencie łączy się z pierwszym przykazaniem, stąd też nasza uwaga znów będzie skoncentrowana na drzewach rosnących w ogrodzie Eden.

\section{UKIERUNKOWANIE NA TRANSCENDENCJĘ}

Ciekawe, że drzewa w obu opowiadaniach są stworzone jako jedne z pierwszych elementów świata ożywionego, wobec czego trudno jest przy lekturze ciągłej utrzymywać popularną hipotezę, że owo wyjątkowe drzewo miało pełnić funkcję „sprawdzenia” człowieka, wystawienia go na próbę. Człowiek, jako konkretna istota, uczyniona w konkretnym świecie, jest „jakiś”, czyli ma swoje możliwości i ograniczenia. Mówiąc bezpośrednio - nie jest Bogiem, stąd też w interakcji ze światem musi zdawać sobie sprawę z uwarunkowań swojej natury oraz świata, w którym żyje. Tym samym wracamy do etycznego wymiaru jego egzystencji i panowania nad powierzonym mu światem.

Zakładając prawdziwość tezy, iż Bóg, jako Stwórca i źródło wszelkich dóbr, umieszczając Adama w ogrodzie pozostawia go samego, pierwsze przykazanie nabiera szczególnego znaczenia. Chociaż zawiera $\mathrm{w}$ sobie dwa elementy, przyzwolenie i zachętę z jednej strony i zakaz wraz z ostrzeżeniem z drugiej, koncentruje uwagę czytelnika głównie

37 Zob. TWOT, art. 2243.

38 TWOT, art. 1323.

39 Por. Sdz 2,23 (JHWH pozostawia w spokoju narody, „nie wyganiając ich spiesznie i nie wydając ich w ręce Jozuego"); 1 Sam 10,25 (Samuel odsyła lud do domu); zob. TWOT, art. 1323; HALOT, art. 6038. 
na zakazie. Zauważa to Z. Pawłowski, wskazując na specyfikę retoryki zakazu Rdz 2,16-17, opierającej się głównie na użyciu konkretnych terminów wskazujących na „drzewo znajomości dobra i zła” w zestawieniu z ogólnymi i lakonicznymi sformułowaniami wyrażającymi przyzwolenie na spożywanie owoców ze wszystkich drzew ogrodu ${ }^{40}$. M. Grabowski, proponując dwie drogi odczytywania omawianego tekstu, dosłowną i symboliczną, w przypadku tej pierwszej także nie widzi w zachęcie większego znaczenia $^{41}$. Sytuacja zmienia się przy odczytaniu opowiadania o Edenie w kluczu symbolicznym, kiedy to drzewa postrzegane są jako „sposoby dostępu do wartości” ${ }^{2}$. W takiej optyce słowa: „Możesz jeść do woli ze wszystkich drzew ogrodu [...]" (Rdz 2,16) otwierają przed człowiekiem „perspektywę nieograniczonych możliwości zaspokajania pragnień” ${ }^{3}$. Koresponduje to z nowotestamentową uwagą św. Pawła: „Wszystko mi wolno, ale nie wszystko jest pożyteczne. Wszystko mi wolno, ale ja niczemu nie poddam się w niewolę" (1 Kor 6,12, BPaul). Zakaz wprowadzony przez Boga to ostrzeżenie przed konsekwencjami ludzkich wyborów, ale także informacja dla czytelnika, że człowiek i jego własne pragnienia nie mogą być podstawowym punktem odniesienia i kryterium szczęścia. Doskonale widać to w zakończonych w 2013 roku badaniach kondycji psychicznej Polaków, EZOP, według których u blisko 1/4 dorosłej populacji (dokładnie 23,4\%) w wieku 18-64 lat można w ciągu życia zdiagnozować przynajmniej jedno z zaburzeń związanych z używaniem substancji

40 „Dowodem skuteczności tej strategii [retoryki zakazu - przyp. K.P.] jest fakt, iż większość komentarzy koncentruje się prawie wyłącznie na zakazie, pomijając całkowicie przyzwolenie lub wspominając o nim tylko mimochodem”. Zob. Z. Pawłowski, Opowiadanie, Bóg i początek. Teologia narracyjna Rdz 1-3, Warszawa 2003, s. 364-365 (cyt. s. 365, przyp. 56).

${ }^{41}$ „Interpretacja dosłowna, w której drzewa są tylko drzewami [...], sprawia, że zachęta: $Z$ wszelkiego drzewa tego ogrodu możesz spożywać według upodobania nie wnosi żadnej istotnej treści. Pozostaje tylko druga część polecenia, w której na plan pierwszy wysuwa się zakaz: $z$ drzewa poznania dobra i zła nie wolno ci jeść. Nie odnosi się do zachowań społecznych, moralnych, ale jest religijnej natury, co znaczy, że swe uprawomocnienie, treść i znaczenie czerpie bezpośrednio ze sfery tego, co Boskie. Edeńskie polecenie staje się $\mathrm{w}$ ten sposób przedstawieniem religijnego zakazu. Takiej redukcji dokonuje interpretacja dosłowna”. M. Grabowski, Historia upadku, s. 116.

${ }^{42}$ M. Grabowski, Historia upadku, s. 116.

${ }^{43}$ Z. Pawłowski, Opowiadanie, Bóg i początek, s. 365. 
psychoaktywnych, zaburzeń nastroju, nerwicowych (w tym lękowych i neurastenii) oraz zaburzeń kontroli impulsów i zachowań autodestrukcyjnych. Po ekstrapolacji na populację generalną daje to liczbę ponad sześciu milionów mieszkańców Polski w wieku produkcyjnym ${ }^{44}$. Około 20-30\% populacji uskarża się na następujące problemy: stany obniżenia nastroju i aktywności, swoiste objawy unikania, przewlekły lęk, drażliwoś $^{45}$. Bycie dla siebie punktem odniesienia napotyka w perspektywie biblijnej na zasadniczą trudność - człowiek, jako istota stworzona przez Boga i ukierunkowana na Niego, nawet w głębokiej relacji międzyludzkiej odczuwać może swoisty brak, w myśl słów św. Augustyna: „Stworzyłeś nas [...] jako skierowanych ku Tobie. I niespokojne jest serce nasze, dopóki w Tobie nie spocznie" ${ }^{46}$. Nie bez znaczenia są dalsze słowa Augustyna: „[...] czy w ogóle można Cię wzywać, zanim się Ciebie pozna? [...] Przecież mógłby wtedy człowiek, myląc się, coś innego przyzywać! [...]”47.

\section{ZAKOŃCZENIE}

W niniejszym artykule wskazaliśmy tylko na wybrane wątki z opisów stworzenia Adama i Ewy. Nie poruszyliśmy niezwykle istotnego tematu grzechu pierworodnego czy kwestii nagości i wstydu, ale wówczas tekst musiałby być znacznie dłuższy, stąd też zagadnienia te znajdą miejsce w odrębnych opracowaniach. Widzimy jednak wyraźnie biblijną koncepcję komplementarności mężczyzny i kobiety, przy czym charakteryzuje ją zarówno wzajemna odmienność, jak też swoista nieadekwatność polegająca na tym, że para ludzka sama w sobie nie jest wystarczająca do tego, aby stworzyć i doświadczyć pełni szczęścia. Wspólne ukierunkowanie na Boga to zasadniczy rys zarówno chrześcijańskiej antropologii, jak też teleologii wszelkich działań pomocowych, także psychologicz-

${ }^{44}$ Epidemiologia zaburzeń psychiatrycznych i dostęp do psychiatrycznej opieki zdrowotnej - EZOP Polska. Zob. udostępniony online 5 rozdział pełnego raportu $\mathrm{z}$ badania Podsumowanie - rozpowszechnienie, bariery i rekomendacje, http://www.ezop.edu. pl/05-Podsumowanie.pdf, s. 267 (dostęp: 07.08.2019).

45 Tamże, s. 268.

${ }^{46}$ Św. Augustyn, Wyznania, I, 1, tłum. Z. Kubiak, Warszawa 1978, s. 5.

47 Tamże. 
nych. Zauważmy na koniec, że konieczność wzajemnego poznawania się w swoim człowieczeństwie i wspólnego wędrowania ku konkretnemu, osobowemu Bogu jest koncepcją zdecydowanie bardziej zakorzenioną w rzeczywistości niż postmodernistyczne i skrajnie egocentryczne wizje indywidualnego przebóstwienia, tak popularne w zachodnim świecie w postaci kursów medytacji i samorozwoju o pozornych proweniencjach kultur i religii Wschodu ${ }^{48}$. Szukanie bóstwa w sobie sprawia, że w relacji szukamy nie partnera, a wyznawcy, bo selfistyczny bóg XXI wieku jest bogiem zazdrosnym. Chrześcijaństwo ze swoją antropologią, świadomością ludzkiej ograniczoności, grzeszności i powołania do świętości, realizowanej poprzez miłość bliźniego, nie ma tu prawdziwej konkurencji, ucząc poznawania siebie poprzez relację z Innym.

\section{BIBLIOGRAFIA}

Abarim Publications' online Biblical Hebrew Dictionary, http://www.abarim-publications. com/Meaning/Eve.html\#.Wi_VsnlG2M- (dostęp: 12.12.2017).

Augustyn, Wyznania, I, 1, tłum. Z. Kubiak, Warszawa 1978.

Berachot, https://halakhah.com/pdf/zeraim/Berachoth.pdf (dostęp: 30.11.2017).

Briks P., Podręczny słownik hebrajsko-polski i aramejsko-polski Starego Testamentu, Warszawa 1999.

Eldredge J. i S., Urzekająca. Odkrywanie tajemnicy kobiecej duszy, Warszawa 2011.

Eldredge J., Droga dzikiego serca, Warszawa 2013.

Eldredge J., Dzikie serce. Tęsknoty męskiej duszy, Poznań 2003.

Eldredge J., Petnia serca, Poznań 2012.

Epidemiologia zaburzeń psychiatrycznych i dostęp do psychiatrycznej opieki zdrowotnejEZOP Polska. Podsumowanie - rozpowszechnienie, bariery i rekomendacje, http:// www.ezop.edu.pl/05-Podsumowanie.pdf (dostęp: 07.08.2019).

Eruvin, http://halakhah.com/pdf/moed/Eiruvin.pdf (dostęp: 30.11.2017).

Grabowski M., Historia upadku. Ku antropologii adekwatnej, Kraków 2011

Harris R.L., Archer, Jr. G.L., Waltke B.K., Theological Wordbook of the Old Testament, Chicago, Illinois 1980.

Jan Paweł II, Mężczyzna i niewiasta stworzył ich: odkupienie ciała a sakramentalność małżeństwa, Watykan 1986.

Koehler L., Baumgartner W., Stamm J.J., The Hebrew and Aramaic Lexicon of the Old Testament (dalej: HALOT), CD-ROM Edition, Leiden 2000.

${ }^{48}$ A. Zwoliński, Psychologia zamiast religii?, s. 61-166. 
Koehler L., Baumgartner W., Stamm J.J., Wielki słownik hebrajsko-polski i aramejsko-polski Starego Testamentu (dalej: HALOTpl), red. pol. P. Dec, t. I, Warszawa 2008.

Midrasz Bereszit Rabba 8, 1; https://archive.org/stream/RabbaGenesis/midrashrabbahgen027557mbp\#page/n101/mode/2up (dostęp: 30.11.2017).

Niemirowski T., O możliwości psychologii chrześcijańskiej, Płock 2010.

Ostaszewska A., Psychoterapia integratywna w ujęciu chrześcijańskim, Sopot $2017^{2}$.

Pawłowski Z., Narracja i egzystencja. Genesis w hermeneutyce opowieści, Toruń 2013.

Pikor W., Pytanie o „obraz i podobieństwo” Boże w człowieku (Rdz 1-2), w: Człowiek ciało i duch. Tom 2. Ujęcie teologiczne, red. K. Krzemiński, K. Olszewska, R. Beszterda, Toruń 2015, s. 31-45.

Popowski R., Biblia pierwszego Kościoła, Warszawa 2016.

Trigano Sh., Judaizm: „Mężczyzną i niewiasta stworzył ich”, w: Encyklopedia religii świata, t. 2: Zagadnienia problemowe, red. F. Lenoir, Y. Tardan-Masquelier, M. Meslin, J.-P. Ros, Warszawa 2002, s. 1661-1665.

Trudne fragmenty Biblii, red. W.C. Kaiser Jr., P.H. Davids, F.F. Bruce, M.T. Brauch, Warszawa 2011.

Vitz P.C., Psychologia jako religia, Warszawa 2017.

Wulff D.M., Psychologia religii, Warszawa 1999.

Zwoliński A., Psychologia zamiast religii? Pułapki i manipulacje, Kraków 2019. 